\title{
Performance e disrupção: arte-ativismo hacker
}

\author{
Daniel Hora*
}

Universidade de Brasília

\begin{abstract}
Resumo
O tema desta reflexão é a correlação entre performance artística e arte-ativismo hacker. Adotaremos a produção informacional como axioma para concepções ampliadas de corpo e linguagem, performance maquínica e espaço. A partir de Jon Mckenzie, consideraremos três orientações de interesse: a eficiência buscada pela performance corporativa, a efetividade almejada pela performance tecnológica e a eficácia requerida à performance artístico-cultural. Em seguida, comentamos alguns embates entre as corporificações e codificações artísticas, técnicas, políticas e econômicas. Por fim, revisaremos questões relativas às condições de resistência configuradas pela espacialidade e temporalidade telemática, em que coabitam e se entrelaçam diversas modalidades de performance.
\end{abstract}

\section{Palavras-Chave}

Performance maquínica, arte-ativismo hacker, reprogramabilidade, disrupção

\section{Performance and disruption: hacker art-activism \\ Abstract}

The subject of this reflexion is the correlation between performance art and hacker art-activism. We adopt the informational production as an axiom for expanded conceptions of body and language, machinic performance and space. Following Jon McKenzie, we consider three directions of interest: the effficency sought by corporate performance, the effectiveness expected from technological performance, and the efficacy required to artistic and cultural performance. Then we comment on some conflicts between artistic, technical, political and economic embodiments and codifications. At last, we review issues related to resistance conditions set by telematic spatiality and temporality, in which different modalities of performance cohabit and intertwine.

\section{Keywords}

Machinic performance, hacker art-activism, reprogrammability, disruption.

\footnotetext{
" É bolsista de pós-doutorado da Capes, vinculado ao Programa de Pós-Graduação da Faculdade de Arquitetura e Urbanismo da Universidade de Brasilia (UnB). Atua como pesquisador colaborador do Núcleo de Estética, Hermenêutica e Semiótica, sob a supervisão do Prof. Dr. Miguel Gally. É mestre e doutor em Arte Contemporânea pela UnB e bacharel em Comunicação Social pela Universidade de São Paulo. Em suas atividades de pesquisa e docência, dedica-se ao estudo teórico da transgressão tecnológica nas artes visuais, mídia, arquitetura e urbanismo. Conduziu sua pesquisa de doutorado sob orientação da Profa. Dra. Maria Beatriz de Medeiros (UnB) e fez estágio sanduíche na Universidade da Califórnia, em San Diego, sob a supervisão do professor Brett Stallbaum. Recebeu em 2009 o prêmio Rumos Itaú Cultural Arte Cibernética, na categoria pesquisa acadêmica (danielhora@unb.br).
} 


\section{Reprogramabilidade e corporificação}

A performance transborda. Extrapola a posição de um objeto entre outros, internalizado por uma ou várias disciplinas. É mais que um único problema. Certamente, podemos reconhecer a correlação entre a proeminência atual da performance e a expansão do caráter processual da indústria baseada na informação. Mas a produção ancorada na codificação da imaterialidade não é a causa exclusiva do atual extravasamento da performance. Pelo contrário, talvez seja mais um efeito que retroalimenta aquilo que o provoca.

A disseminação da performance é produto do modo instável e híbrido de sua existência. Uma existência poiética cujo caráter biológico, mas também tecnológico, remete a tempo remoto. Mas que se torna cada vez mais difuso com os automatismos dos aparelhos, sobretudo, desde o impulso recebido com o protótipo teórico da máquina universal de Alan Turing. Segundo esse modelo, surgem as diversas implementações dos chamados dispositivos de metamídia (Manovich, 2013), plataformas de atuação substitutiva, que emulam o comportamento de qualquer outra mídia programável destinada ao processamento da informação.

Em conjunto com essa propagação algorítmica, a performance se alastra em sua abrangência conceitual. $O$ contexto da difusão de instruções abstraídas em códigos (em acoplamentos sensório-cognitivos orgânicos e artificiais) reforça o caráter discursivo e analítico da inscrição do agente que performa. Porém, a performance já remete à linguagem, antes mesmo de qualquer automação lógica. Não o contradiz a afirmação de que seu valor corresponde ao processo. Pois o processo constitui-se como uma 
linguagem no decurso de sua inflação, aquilo a que Jacques Derrida se refere com a différance (1973).

Conforme essa acepção, a linguagem, quando fixada em signos, escritura ou traço, é apenas um, ou o composto, dos fluxos processuais apreendidos em algum suporte de acolhimento. Por sua vez, essa linguagem estancada não se estabiliza. Porque forma um agregado de pontos de retenção que viabiliza a consecutiva protensão operacional. A linguagem é -grama, marca sedimentar ou, talvez, erosiva. A performance está para ela como um programa em execução adaptativa. Pois se abre para a reprogramabilidade, isto é, a retomada que encadeia outras linguagens.

Graças à disposição reticulável de seus traços de retenção e protensão, a performance se estabelece na alteridade operacional. Isto é, compõe-se com e pelo conjunto de situações capaz de ativar a relacionalidade dos sistemas, pela conjugação entre um e outro, dentro e fora, biológico e sintético, pertencimento e exclusão, sensível e inteligível, 0s e 1s. Nessa conjugação, percorre as extensões do vivo ao algorítmico. Faz também emergir os hibridismos extraídos da exploração e da transgressão dos condicionamentos lógicos e físicos dos dispositivos.

Compreendida segundo as suas decorrências e impactos informacionais, a performance se aproxima de um gesto reprogramador. Então pode ser entendida como uma ação hacker, segundo o jargão atribuído à transgressão tecnológica. Mas tal gesto não conduz somente à propagação da liberdade. A ação hacker tende à rebeldia contra o estabelecido, de um lado, em favor de agentes desfavorecidos no jogo informacional. Mas há também a sua cooptação direcionada a objetivos restritivos e de distinção socioeconômica.

Isso acontece porque a perspectiva informacional impulsiona ao menos três vertentes conflitantes de performance, conforme podemos observar a partir 
de Jon McKenzie (2001, 2005). Corporações performam. Tecnologias performam. Agentes culturais (e artistas) performam. Essa concepção indica que a performance constitui diagramas distintos de poder.

A cada vertente corresponde um desafio próprio e, em geral, incongruente com a satisfação dos demais. As corporações buscam eficiência, o maior retorno ao menor custo. As tecnologias se dedicam à efetividade, à excelência funcional. Os artistas almejam a eficácia, a corroboração (inclusive involuntária) ou a transformação (planejada ou acidental) das estruturas sociais.

Contudo, embora existam interesses distintos, há uma trilha que Ihes atravessa. Pois o que performa é um corpo. Mas, digamos aqui, em sentido abrangente: um corpo organizacional, um corpo tecnológico, um corpo artístico-cultural, assim como as suas conexões intermediárias e as demais composições extravagantes - que se conjugam com os domínios dos animais, dos vegetais ou todo ambiente.

Seguindo Gilles Deleuze (2002), a noção estendida do corpo articula, portanto, as várias composições concretas em que se verifica a performance. Mesmo quando não se refere a um organismo biológico isolado, a capacidade receptiva e propositiva de afecção atribui corpo, corporifica, aos variados conjuntos de elementos relacionais.

Com essa corporificação, reconstituem-se as expressões embodiment ou incarnation, encontradas na ciência cognitiva e fenomenologia. Seguimos, com Deleuze, o desdobramento da inerência corpórea do pensamento. Percorremos assim uma via pós-antropocêntrica, ou pós-antrópica, já que além da ruptura com a centralidade há o afastamento das órbitas temáticas (trópos) humanas. 
Com a corporificação, pensamos a relação entre os suportes de inteligência e a perceptividade humana e inumana. Nesse sentido, a corporificação se refere à relacionalidade subjetiva-objetiva que resulta do que Gilles Deleuze e Félix Guattari (1995b: 29) denominam os agenciamentos maquínicos, cooperações de "de corpos, ações e paixões", e os agenciamentos coletivos de enunciação, cooperações "de atos e de enunciados, transformações incorpóreas [...] atribuídas aos corpos".

Corporificar é ainda transpor ao tátil ou sensorial qualquer processo imperceptível por si mesmo, de imediato. Torna-se então reconhecido 0 sub-reptício - tanto da ordem inteligível, quanto da dos afectos de ação e paixão, na concepção espinosista presente em Deleuze (2002). Porque a incógnita se faz observável (e manipulável) a partir de sua manifestação concreta. Nesse sentido, a corporificação se aplica, mas não se reduz às conotações espirituais ligadas à encarnação e incorporação. Tampouco se limita à extensão da propriedade, como ocorre na incorporação acionária e imobiliária1. Não se restringe ainda à expansão de volume, como 0 encorpamento.

No que se refere à produção informacional, a corporificação serve à atualização "do potencial das tecnologias digitais (realidade virtual) para alterar o mundo-da-vida" (Hansen, 2006: 28-29)2. A performance expandida e expansível da corporificação remete, portanto, ao transbordamento (e à reprogramação) da materialidade que a sustenta. Pois expressa as dinâmicas que são subjacentes à sua instanciação em circunstâncias peculiares em constante transição.

Cada corpo afeta e é afetado por meio de algo semelhante a um "código", ou estrutura efêmera, que passa pela constante recomposição propiciada

1 Essa conotação persiste parcialmente pertinente à nossa reflexão sobre agenciamentos excedentes da subjetividade, nos casos citados adiante em que nos referimos à contestação contra o poder das corporações econômicas.

2 Tradução nossa.

Revista do Programa de Pós-graduação em Arte da UIS V.15, n⿳01/janeiro-junho de 2016 
pelo contato com a alteridade. Essa maleabilidade ampara a capacidade autopoiética da performance. Possibilita, portanto, uma produção autônoma e sistêmica em contrapartida com o que se encontra alheio em algum campo topológico e cronológico contatável.

A reprogramabilidade decorrente da performance da corporificação é resultante da participação estética, ética e cognitiva do agente que age em um determinado ambiente e, com isso, gera sinais e as respectivas sintaxes. Como a linguagem, o código afirma-se como ponto de retenção e de protensão. É estabelecido em ato, e se relança em subsequentes reinstaurações - corporativas, tecnológicas, artísticas e muitas outras.

Em mútua decorrência, corporificação e codificação fazem a performance atravessar múltiplas circunstâncias. Como aponta Jon McKenzie (2005: 23), essa transversalidade caracteriza a "performance maquínica". Isto é, a recorrência ou a comunicação de processos diferenciais distribuídos que perpassam sistemas distintos. As interações decorrentes englobam múltiplos participantes, e "escapam ao controle subjetivo e, inclusive, à análise objetiva". Porque mesmo a reflexão a seu respeito se torna participante da performance maquínica.

Essa transversalidade traz consigo mais um desafio. Incita o discernimento sobre os modos de entrelaçamento das vertentes da performance maquínica. Perguntas abertas: em que situações a reprogramabilidade hacker é eficaz em contraponto com a efetividade tecnológica e a eficiência corporativa? É essa eficácia que confere valor à arte, em oposição à não arte? Faz sentido fixar uma analogia entre a arte da performance e 0 ativismo hacker? Quais seriam os efeitos recíprocos desse intercâmbio de concepções? 


\section{Arte, política, concatenações e disrupção}

Anonymous e WikiLeaks ${ }^{3}$ não produzem arte - ao menos, de modo autodeclarado ou por reconhecimento institucional plenamente difundido. No entanto, a notoriedade alcançada pelas iniciativas correspondentes às duas denominações deve ser tomada como uma referência no mínimo comparativa para tantas outras ações semelhantes, no Brasil e no mundo. $\mathrm{Na}$ exterioridade, mas também dentro do campo da arte, as corporificações e performances de Anonymous e WikiLeaks constituem uma exemplaridade incontornável para se pensar as caraterísticas políticas da produção artística e ativista de orientação hacker.

A condenação e o culto ao que se realiza segundo os preceitos ou sob as alcunhas de Anonymous e WikiLeaks oscilam de modo semelhante às polêmicas do sistema artístico. Pelo encontro dessas reações, orientam-se as disputas pelas significações concedidas aos entrelaçamentos entre arte e ativismo (tecnológico), bem como a suposição de predomínio de um dos dois lados sobre o outro. O ativismo instrumentaliza, é refletido ou é intrínseco à arte? Ou, em vez disso, suas respectivas performances maquínicas poderiam se concatenar de modo transversal, conforme Gerald Raunig (2007)? E nessa transversalidade, que arranjos temporários e disruptivos seriam possíveis, sem que uma parte absorva, mas desfaça a estabilidade prévia e propicie o fluxo da outra?

Entre arte e ativismo é possível encontrar mútuas referências que corroboram a perspectiva de uma concatenação isenta de uma solução dialética sobre qual termo é continente e qual é conteúdo. Em vez da separação ou a indistinção radical, as performances da arte, da tecnologia, da economia e da política podem persistir em intercâmbios variáveis. Suas trocas são moduladas por circunstâncias incongruentes que desafiam e

\footnotetext{
3 Site Anonymous. Dispoível em: http://www.anonews.co/ (agregador de notícias sobre a legião descentralizada de ativistas) e Site WikiLeaks. Disponível em https://wikileaks.org/. 
(re)configuram os campos discursivos, em correlação com a multipolaridade da sensibilidade, da tecnociência e do poder.

Assim, 0 arte-ativismo 4 hacker (ou hacktivismo artístico) dá continuidade ao histórico de concatenações entre máquinas poéticas e políticas apresentado por Raunig. Nessa linhagem, incluem-se exemplos como a transmissão ininterrupta do artístico para o político na Internacional Situacionista, bem como as sobreposições episódicas com os movimentos antiglobalização desde a década de 1990. Além disso, os desdobramentos conferidos na conjunção do arte-ativismo hacker fazem convergir os termos de desterritorialização e reterritorialização conceitual. Pois a recíproca transferência de noções entre a ética e estética é acompanhada pela contínua remarcação diferencial das margens de compartimentação.

De uma parte, a estética está presente na amplificação sensorial que ampara os protestos legionários em defesa da liberdade perpetrados pelo Anonymous, bem como os vazamentos de dados confidenciais compartilhados por colaboradores incógnitos via WikiLeaks. No que se refere aos efeitos de conscientização pública, parte do êxito obtido por ambas as formas de performance e ativismo se deve ao uso de recursos de retenção e protensão em linguagens textuais, visuais e audiovisuais em suas campanhas. Pois a eficácia da crítica artistico-cultural requer apelo ao senso coletivo, de modo que se possa estabelecer o combate contra a espetacularização estética opressora empregada para assegurar 0 predomínio da efetividade tecnológica e da eficiência corporativa conforme os desafios performativos propostos por Jon McKenzie (2001).

As modalidades sensoriais de afirmação discursiva da rede Anonymous abrangem, como código imediato, as máscaras do conspirador britânico Guy Fawkes 5 que disfarçam o rosto de manifestantes. Em segundo lugar,

\footnotetext{
4 Preferimos utilizar a expressão arte-ativismo em lugar de artivismo. Sublinhamos assim a ideia de concatenação presente em Raunig e também discutida no Brasil por Fernando Gonçalves (2010) e André Mesquita (2006; 2011).

${ }^{5}$ Guy Fawkes foi um dos 13 conspiradores que planejaram explodir o parlamento de Londres em 1605, para assinar 
há os comunicados em vídeo produzidos em torno de campanhas como Operation Payback. Nesse conjunto de ataques contra corporações financeiras e conglomerados de mídia intitulada perpetrado em 2010, os ativistas visam atingir as atividades de representantes da indústria cultural, em virtude de políticas de copyright consideradas totalitárias. Também são alvo as instituições financeiras responsáveis pelo bloqueio das contas até então usadas para o envio de doações ao WikiLeaks.

Nessa operação, a multidão assume uma identidade simbólica para derrubar, desfigurar e desbloquear dados privados de sites de corporações interessadas na punição de pessoas envolvidas no compartilhamento de arquivos de obras audiovisuais e de músicas na internet - a exemplo da Motion Picture Association of America (MPAA, associação da indústria audiovisual dos EUA), Recording Industry Association of America (RIAA, associação da indústria fonográfica dos EUA). Em seguida, a ira se volta contra os sites dos responsáveis por interditar a arrecadação de fundos para o WikiLeaks - entre outros operadores, as empresas PayPal, Amazon, MasterCard e Visa.

No entanto, para além dessa camada de visibilidade na mídia, a estética comunitária da rede Anonymous é expressa também na tecnologia. Com frequência, torna-se inscrita nas próprias linhas da escrita dos softwares adotados em suas práticas (Serracino-Inglott, 2013). Por outra parte, as táticas de abertura reviram as significações implícitas que afetam a legitimidade e o valor de uma experiência humana baseada na tecnologia. Desse modo, a eficácia da performance artística e cultural, aderente ao ativismo, se estabelece em contraponto à efetividade do funcionamento das redes telemáticas de informação e à eficiência das operações capitalistas.

o rei e os lordes e provocar uma reviravolta política na Inglaterra destinada à substituição do monarca e o retorno do país à religião católica. A máscara no formato de seu rosto estilizado é tradicionalmente colocada em um boneco referente ao personagem histórico, na data comemorativa de sua captura e apreensão do material explosivo. Sua adoção por ativistas da rede Anonymous e movimentos Occupy se inspira em sua utilização como elemento narrativo da história em quadrinhos V de Vingança, de 1982. Fontes: http://www.gunpowder-plot.org/ e http://en.wikipedia.org/. 
A recorrente zombaria anárquica e rebelde da rede Anonymous recebe ainda acolhimento temporário no campo da arte, quando consideramos a conotação poética e estética atribuída a algumas de suas ações, segundo a perspectiva etnológica de Gabriella Coleman (2014b). Há ainda o caso da exposição Networked Disruption: Rethinking opositions in art, hacktivism and business ${ }^{6}$, montada em Ljubjana (Eslovênia) em 2015, com a curadoria de Tatiana Bazzichelli. Nessa mostra, registros de ações da legião Anonymous se unem a peças de projetos coletivos e individuais, como 0 grupo Telekommunisten (baseado em Berlim), a dupla italiana Les Liens Invisibles e o neozelandês Julian Oliver (Bazzichelli, 2015).

Por sua vez, a repercussão constante do ativismo do WikiLeaks deriva inicialmente das táticas usadas nos anúncios públicos dos documentos vazados. Em seguida, devemos considerar a divulgação de vídeos como Assassinato Colateral, gravação vazada em 2010 que demonstra a morte de civis iraquianos pelas forças armadas dos EUA. Por fim, temos a própria figura midiática de Julian Assange, líder do projeto exilado na Embaixada do Equador em Londres desde 2012, em razão do risco de sua deportação para a Suécia e Estados Unidos, países em que responderia respectivamente por acusações de supostos abusos sexuais e de crimes de espionagem, conspiração, roubo de dados e fraude cibernética.

A entrevista de Assange feita pelo curador Hans-Ulrich Obrist (2011a, b), com a inclusão de perguntas elaboradas por artistas como o chinês Ai Weiwei e o coletivo dinamarquês Superflex, demonstra o interesse ou, mesmo, a adesão artística aos propósitos políticos do WikiLeaks de oferecer ao conhecimento público informações secretas de governos e da diplomacia internacional.

6 Site Networked Disruption: rethinking oppositions in art, hacktivism and business. Disponível em: http://aksioma.org/networked.disruption/. 
Outra concatenação ocorre no trabalho do coletivo anglo-suíço !Mediengruppe Bitnik 7 . Delivery for Mr. Assange (2013) é um projeto realizado durante as 32 horas de entrega postal de um pacote endereçado pelos artistas a Julian Assange. Por meio de um orifício na embalagem, uma pequena câmera registra e transmite para a internet imagens do percurso de transporte. Com isso, os artistas testam o funcionamento do sistema de correio, assegurando visibilidade a eventuais interceptações ou violações indevidas da correspondência.

Em contrapartida aos empréstimos estéticos do ativismo, reverberam nas táticas artísticas alguns aspectos operacionais das iniciativas da rede Anonymous e do WikiLeaks. Entre os fatores comuns estão o coletivismo da ação direta e seu hibridismo com corporificações tecnológicas. Ataques de negação de serviço (DoS) visam interromper ou desviar o uso de forças por parte de um agente opressivo. Para isso, dependem de voluntários ou do uso de agentes inteligentes (botnets ${ }^{8}$ ). Nesse sentido, encontramos analogias com a arte participativa herdeira dos happenings da década de 1960.

Essas duas vertentes de performance estão conjugadas em projetos como Tactical Zapatista FloodNet (1998, Figura 1). Nesse trabalho, o coletivo estadunidense Electronic Disturbance Theater ${ }^{9}$ (em atividade desde 1997) disponibiliza um sistema para ações de desobediência civil eletrônica. Por meio dele, cerca de 10 mil indivíduos dispersos se engajam em protestos

\footnotetext{
7 Dupla formada por Domagoj Smoljo e Carmen Weisskopf. Trabalhos documentados em seu endereço na internet: https://wwwwwwwwwwwwwwwwwwwwww.bitnik.org/.

$8 \mathrm{Um}$ ataque DoS (denial of service) é o incidente em que um usuário é privado do acesso a serviços em rede por efeito de uma ação distribuída. Nesse tipo de ataque, um elevado número de sistemas envolvidos (botnets) ou de usuários atingem um alvo específico. Por sua vez, um botnet (também chamado de exército zumbi) corresponde a computadores conectados programados para participar de transmissões de dados a outros computadores (incluindo spam ou vírus), embora seus proprietários em geral não saibam disto. As máquinas transformadas em botnets podem redirecionar as transmissões para um alvo determinado, como um servidor de um web site cujo funcionamento é interditado pelo excesso de tráfego (Rouse; Wigmore, 2014).

9 Site b.a.n.g. lab / EDT 2.0. Disponível em http://bang.transreal.org/; Site Eletronic Civil Disobedience. Disponível em: http://www.thing.net/ rdom/ecd/ecd.html. 
virtuais contra a opressão neoliberal e em apoio ao movimento rebelde dos indígenas zapatistas (Denning, 2001).

Ao carregar uma página web, os ativistas acionam uma aplicação para envio de mensagens com nomes de indígenas assassinados pelas forças armadas mexicanas e expressões associadas às suas lutas contra o poder. O objetivo é sobrecarregar e interferir no funcionamento de sites escolhidos como alvo: presidências do México e EUA, bolsas de valores mexicana e de Frankfurt, Pentágono e bancos (Tribe; Jana, 2006). Como não há registro das vítimas nos bancos de dados, a capacidade dos servidores é desviada para a tarefa vã de informar essa inexistência e acrescentar 0 evento ao arquivo de registro de ocorrências (log) dos sistemas assediados (Raley, 2009).

Assim, a mensagem de erro 404 demonstra o que os discursos e ações da hegemonia política não comportam. 0 próprio site atacado reconhece as falhas pela desterritorialização: a justiça, a liberdade ou as vítimas da opressão não são encontradas na lógica institucional corporificada na memória e no ambiente de operacionalidade fornecido por suas máquinas. A efetividade do projeto gera contra-ataques: os sites do Pentágono e da presidência do México passam a utilizar códigos destinados a travar as máquinas dos ativistas pela indução ao recarregamento infinito de dados.

Outra questão comum à conjugação do ativismo hacker e a arte diz respeito ao desvelamento crítico dos dispositivos de dominação social. Esses dispositivos se omitem do público sob o impulso adverso da própria saturação informacional das mídias interativas e da desmaterialização conceitualista (e performática). São fatores de expansão que se tornam, paradoxalmente, obstáculos para a capacidade estética da arte de significação material das dinâmicas de complexidade sociológica. Conforme Brian Holmes (2002), "quanto mais comunicação existe, menos é visível" - e daí podemos inferir por analogia: quanto mais intensidade há 
na performance (maquínica), menos evidência há imediatamente no registro (-grama) de seus processos.

Para lidar com esse problema, WikiLeaks, os projetos brasileiros Transparência Hacker, Ônibus Hacker e Barco Hacker ${ }^{10}$ e 0 analista de sistemas estadunidense Edward Snowden tentam dar visibilidade aos meandros das engrenagens governamentais e corporativas que impactam a vida coletiva. Conflitos de interesse, comportamentos antiéticos, abusos de poder e espionagem irrestrita são denunciados em produções indiciais, icônicos ou alegóricos das práticas sub-reptícias que deturpam regras e garantias democráticas em favor de benefícios escusos.

Essa abordagem fundamenta os projetos de biotecnologia do coletivo estadunidense Critical Art Ensemble - CAE ${ }^{11}$ (em atuação desde 1987). Ao tornar visíveis as suas dinâmicas, os interesses econômicos e os graus de compreensão ou incompreensão social, a encenação almeja uma conscientização crítica dos desafios éticos envolvidos nas aplicações da ciência biológica. As eventuais consequências são exploradas em performances destinadas a provocar o engajamento de seus participantes na propagação de um senso crítico capaz de filtrar cargas ideológicas embutidas nos discursos de autoridade dos especialistas.

Por meio de táticas de dramatização de laboratórios nômades onde são conduzidos experimentos de caráter amadorístico ou paródico, o coletivo CAE estimula a polêmica sobre os rumos das políticas de reprodução assistida e de aperfeiçoamento da espécie humana (projetos Flesh Machine e Cult of the New Eve), os subterfúgios para iludir a rejeição pública à engenharia genética (GenTerra, Molecular Invasion e Free Range Grain), bem como o oportunismo da retomada do discurso e de programas

\footnotetext{
10 Sites consultados: https://groups.google.com/forum/\#!forum/thackday, http://onibushacker.org/ e http://www.barcohacker.com.br/.

11 Sites consultados: http://www.critical-art.net/ e livro publicado pelo próprio coletivo (2012). 
voltados a guerras baseadas em agentes biológicos (Marching Plague e Target Deception).

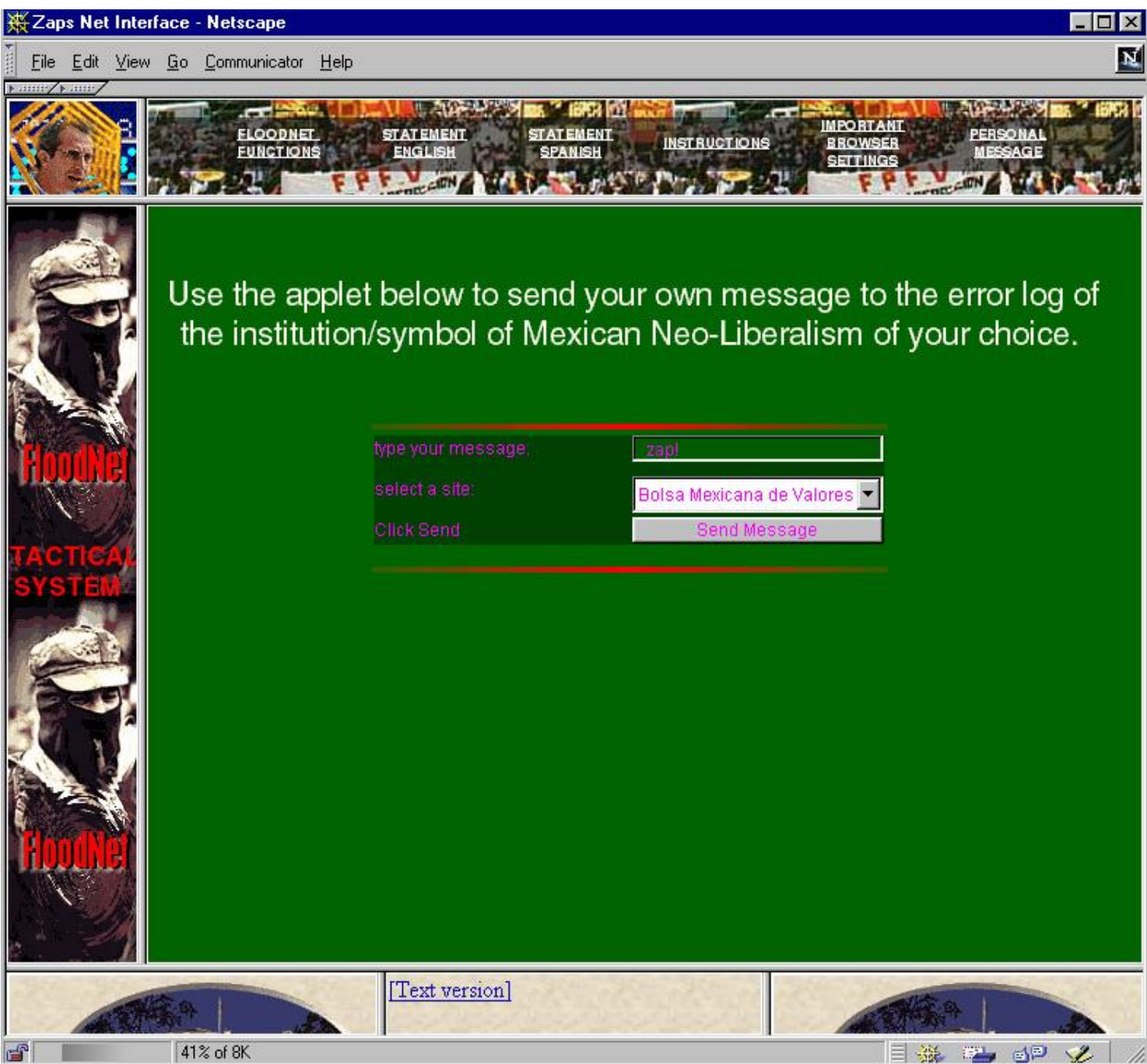

Fig.1: Zapatista Tactical FloodNet (1998), Electronic Disturbance Theater. Fontes: https://wiki.brown.edu/confluence/display/MarkTribe/Electronic+Disturbance+Theater http://www.thing.net/ rdom/ecd/April10.html

Em Flesh Machine (1997-1998), uma companhia fictícia denominada BioCom faz apresentações sobre aprimoramentos tecnológicos do corpo. O público é convidado a realizar um teste para doadores de DNA, em que é possível verificar o valor de mercado de seus organismos. Por sua vez, 
Cult of the New Eve (1999-2000) parodia a apropriação corporativa da retórica de redenção do cristianismo, traduzida em promessas utópicas da biotecnologia. 0 título do trabalho faz referência a uma falsa seita que se opõe a qualquer limite ético à bioengenharia. Em uma de suas performances, os "líderes" da crença oferecem ao público cervejas e biscoitos cujos ingredientes fictícios incluem partes do DNA da Nova Eva, uma suposta doadora de código genético sequenciado pelo Projeto Genoma Humano.

GenTerra (2001-2003) e Molecular Invasion (2002-2004) são laboratórios de ciência teatral. No primeiro projeto, os participantes manipulam amostras transgênicas de bactérias, com o propósito de ampliar seu entendimento sobre os riscos sanitários e ambientais da biotecnologia. Já em Molecular Invasion, o coletivo CAE e as artistas Beatriz da Costa e Claire Pentecost convidam estudantes a desenvolver engenharia reversa de três espécies de vegetais modificados (canola, milho e soja). A proposta é usar substâncias atóxicas para transformar fatores de adaptabilidade em suscetibilidade. $O$ conceito é retomado em Free Range Grain (2003-2004, Figura 2), projeto destinado à verificação do fluxo global da comida transgênica a partir de um laboratório ambulante.

Por último, Marching Plague (2005-2007) e Germs of Deception/Target Deception (2005-2007) abrangem vídeos, apresentações de performances e instalações em torno do resgate narrativo de fracassos ocorridos ao longo da história de tentativas de desenvolvimento de armas biológicas em vários países. A intenção é questionar tanto a propaganda paranoica acerca do bioterrorismo, quanto os recursos desperdiçados em projetos de defesa militar dos EUA voltados a impedir a formação desses hipotéticos arsenais. 

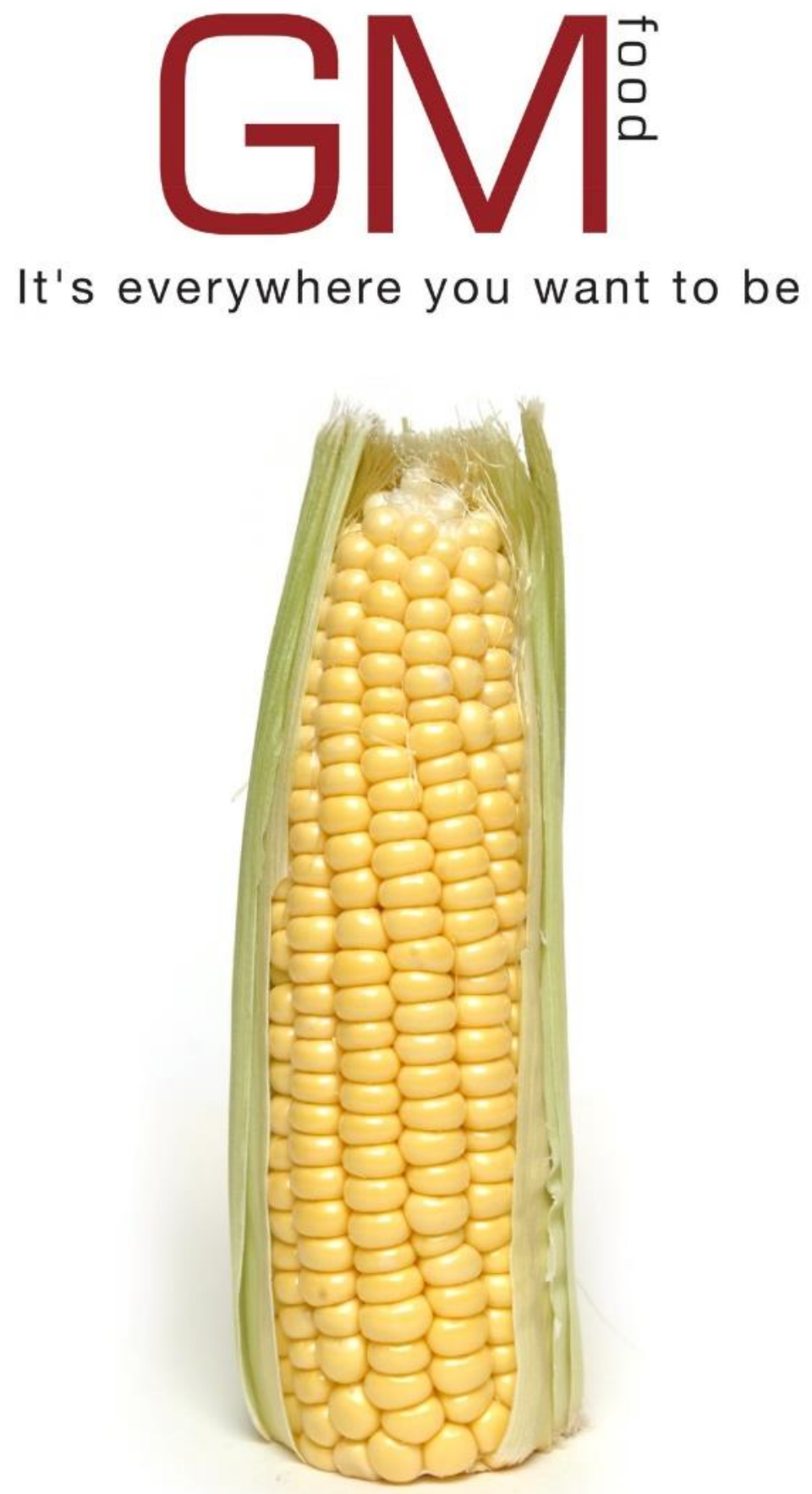

Free Range Grain

A project by Critical Art Ensemble Beatriz da Costa and Shyh-shiun Shyu

Fig.2. Free Range Grain (2003-2004). CAE. Fonte: http://criticalart.net/Images/LG_IMAGES/LG_Biotech/LG_FRG_03.jpg

Revista do Programa de Pós-graduação em Arte da UnB V.15, n11/janeiro-junho de 2016 ISSN- 1518-5494 ISSN (versão eletrônica):2447-2484 
Uma terceira via de concatenação entre arte e ativismo hacker combina a promoção da transparência das instâncias de governança, 0 ataque contra o poder econômico difuso e a pedagogia crítica da sociedade. Neste sentido, a Operação PayBack se converte em modelo de resistência. Pois nesse caso, os Anons (os participantes da rede Anonymous) se engajam na defesa da sustentabilidade financeira dos vazamentos do WikiLeaks ${ }^{12}$.

Em outros casos, as hordas mascaradas, equipadas com suas habilidades computacionais, dão suporte à luta contra a desigualdade econômica por parte do movimento Occupy e dos levantes contra a opressão governamental e policial. Exemplos são encontrados na chamada primavera árabe, nas manifestações contra políticas de austeridade econômica na Espanha ou Grécia e nas mobilizações de junho de 2013 no Brasil, quando consideradas as reivindicações em favor da população ${ }^{13}$.

Temos aí a ativação do método crítico exploratório proposto por Vilém Flusser (2007; 2002). Não é suficiente a denúncia. Tão ou mais urgente é revirar os seus mecanismos de geração e regulação da opressão. Como na fotografia ou no mundo codificado, a informação só pode ser efetivamente avaliada e contrariada pela abertura da caixa preta, ou seja, a decodificação das linhas de instruções computáveis e subjacentes aos fenômenos estéticos.

No campo da arte, devemos mencionar a mobilização para a defesa do coletivo europeu etoy (ativo desde 1994) em seu confronto jurídico com a loja virtual de brinquedos eToys.com. Denominada TOYWAR.com ${ }^{14}$ (19992000), o projeto resulta na vitória dos artistas e ativistas contra a

\footnotetext{
120 apoio ao vazamento de informações corporativas e governamentais segue uma longa tradição do hacktivismo (Coleman, 2014a) .

13 No Brasil ou no exterior, há casos diversos que merecem ser considerados com ponderação. Em contiguidade as reivindicações do ativismo, as ruas e as mídias também foram ocupadas por bandeiras conservadoras ou dirigidas à condenação moralista enviesada de apenas alguma parcela da população e de seu sistema politico.

14 Sites consultados: http://toywar.etoy.com/ e http://history.etoy.com/stories/entries/49/
} 
contestação do uso do domínio etoy.com apresentada aos tribunais pela firma varejista.

A retirada da acusação encerra uma longa disputa, considerada pelo coletivo como "a performance mais cara da história da arte". Essa afirmação se fundamenta no registro de 4,5 bilhões de dólares em desvalorização acionária da companhia durante 0 embate judicial. A perda é provocada pela repercussão de uma ampla campanha de protesto em rede e de uma sequência de interferências eletrônicas que atrapalham o funcionamento do site de vendas da eToys.

Mas o hacktivismo também se dispõe a uma posição de ataque, distinta da disrupção reativa observada na TOYWAR.com. Nessa situação, o recurso da paródia ofensiva desdobra as táticas artísticas de crítica institucional iniciadas na década de 1960, que são desta vez corporificadas por práticas de desconstrução integradas ao poder econômico. 0 arte-ativismo hacker opta pela disrupção comercial (Bazzichelli, 2013). Explora as estruturas que sustentam os negócios, a fim de demonstrar suas contradições e se apropriar de suas lógicas de modo crítico e irônico.

As séries intituladas EKMRZ Trilogy'15 (Trilogia do Comércio Eletrônico) e Hacking Monopolism Trilogy (Trilogia do Hackeamento do Monopolismo) integram as listas de projetos da dupla suíça UBERMORGEN.COM ${ }^{16}$, ativa desde 1995, e dos italianos Alessandro Ludovico e Paolo Cirio ${ }^{17}$. Ambas as trilogias desvirtuam a operacionalidade de grandes empreendimentos do mundo digital - Google, Amazon, Ebay e Facebook.

15 Site EKMRZ Trlgy. Disponível em: http://www.ubermorgen.com/EKMRZ_Trilogy/ e catálogo (Bernhard; Lizvlx; Ludovico, 2009).

${ }^{16}$ Composta por Lizvlx e Hans Bernhard, este também integrante do coletivo etoy.

${ }_{17}$ Site Paolo Cirio. Disponpivel em: http://paolocirio.net/ 
Dois projetos são fruto da parceria entre UBERMORGEN.COM, Alessandro Ludovico e Paolo Cirio. O primeiro é GWEI - Google Will Eat Itself18 (20052009). Nesse trabalho, o sistema de receita publicitária da Google adquire comportamento autofágico e é impelido a uma longínqua e hipotética autoliquidação, prevista para mais de 200 milhões de anos adiante. Seu mecanismo de contabilidade baseada em cliques converte-se em um ciclo automatizado que gera fundos por meio de sites incógnitos com botnets programados para gerar mais acessos aos seus próprios anúncios. Os recursos são usados para a compra de ações da Google, então redistribuídas aos usuários.

O segundo projeto conjunto é Amazon Noir'19 (2006-2007). Consiste na programação de botnets capazes de recompilar livros através do acesso a diversos trechos oferecidos pela função de visualização limitada online. A subversão desse mecanismo de promoção de vendas gera um conflito jurídico. Mais de três mil obras com direitos autorais protegidos são capturadas e disponibilizados em redes de compartilhamento. Representantes da Amazon abrem litígio contra os artistas, e o caso termina com um acordo em que o software é adquirido por meio de um contrato que estabelece sigilo sobre o valor da transação.

Os coletivos seguem depois em projetos separados. A dupla UBERMORGEN.COM completa a série EKMRZ Trilogy com The Sound of eBay20 (2008-2009). O trabalho proporciona um sistema de captação de dados públicos e sigilosos de usuários da plataforma de facilitação de comércio eletrônico. As informações coletadas são transformados em músicas que podem ser baixadas por quem solicita o rastreamento de um usuário da eBay. As notações de cada composição são exibidas em teletexto, em estilo semelhante ao utilizado em antigas publicações de pornografia eletrônica.

18 Site consultado: http://www.gwei.org/

${ }^{19}$ Site Amazon Noir. Disponível em: http://www.amazon-noir.com/

20 Site The Sound of Ebay. Disponível em : http://www.sound-of-ebay.com/ 
Já Alessandro Ludovico e Paolo Cirio concluem a série Hacking Monopolism Trilogy com Face to Facebook ${ }^{21}$ (2011). Nesse trabalho, um software habilita o agrupamento de dados de mais de um milhão de participantes da plataforma de rede social. Um banco de dados é montado com informações publicadas de nome, país de residência, grupos de pertencimento, relacionamentos e foto principal de cada usuário. A partir dessa coleção, um algoritmo de reconhecimento facial categoriza 250 mil perfis e os recontextualiza no site http://www.lovely-faces.com/, dedicado a explicitar a lógica de busca por relacionamentos de amizade e amorosos embutida de modo não explícito na estratégia comercial do Facebook.

As tendências até aqui apresentadas seguem uma classificação apenas esquemática, que não chega a estabelecer a separação entre gêneros artísticos. Conforme a ocasião, a disrupção que atrapalha a ação incontestável dos agentes opressivos não pode subsistir sem uma decorrente conscientização crítica da sociedade. No inverso, a promoção da visibilidade de informações ocultadas pode conduzir ela própria ao distúrbio nos circuitos do poder vigente. Entre uma tendência e outra, diversas combinações são requisitadas.

No conjunto, encontramos, no entanto, tentativas de suspensão ou burla das regras de contenção da ordem do discurso, ou seja, os procedimentos de exclusão e controle das enunciações na sociedade, conforme Michel Foucault (1996). É o que fazem UBERMORGEN.COM, CAE, EDT e outros artistas citados. O programa comum do arte-ativismo hacker consiste em revirar as interdições, a segregação social e a imposição de regras de legitimação da verdade no campo informacional. Assim, as performances tecnológicas, corporativas e culturais são contrastadas com os massacres de minorias indígenas, a repressão à resistência contra a expansão capitalista, a perniciosidade das patentes e dos programas militares de

${ }^{21}$ Site consultado: http://www.face-to-facebook.net/ 
defesa biotecnológica, e as iniquidades por trás dos monopólios em setores da economia.

Para efetuar essas denúncias, a produção hacker altera, por outro lado, os próprios processos internos de regulação discursiva da arte. Em vez de bloqueios, promove lógicas dissidentes de recorrência pelo comentário, joga com os desvios da função-autoria e expande as delimitações da disciplinaridade. A eminência tecnocrática da globalização econômica é citada na contrafação. A autoria se estilhaça com a colaboração coletiva e a participação do público. Passagens se abrem nas fronteiras entre as disciplinas da política, da arte e da tecnologia, e suas respectivas performances.

Em lugar da centralidade de um corpo humano (ou biológico) contido em seus limites, as corporificações distribuídas se alastram. Habitam a viralidade dos trânsitos entre bits e genes ativados sobre a materialidade silícica e carbônica. Fluem, portanto, entre o corpóreo e o informacional, como indica o nome do grupo brasiliense de pesquisa Corpos Informáticos. Pela transdução de tensões vitais para energias eletrônicas, dá-se a disrupção das alianças perversas entre a eficiência organizacional, a efetividade tecnológica e, inclusive, a eficácia cultural.

Essa resistência afeta 0 interior das estruturas diagramáticas de poder. Porque a extensibilidade informacional do corpo também é alvo do aproveitamento estratégico por parte das forças corporativas e estatais, a cada vez que a performance de uma corporificação é reduzida e convertida em mercadoria. Nesse sentido, estamos diante do avanço do pancapitalismo sobre a virtualização da cultura, da bioengenharia e da nanotecnologia, conforme a produção artística e os escritos teóricos do CAE e EDT (2001; Renzi, 2013). 
Informação, DNA e átomos constituem uma triade de exploração capitalista, assumida como foco de investigações pelo laboratório do coletivo Electronic Disturbance Theater, intitulado b.a.n.g (sigla para bits, atoms, neurons, and genes). De modo semelhante, a questão dos projetos do CAE é colocar em pauta as consequências da tecnologia que o público desconhece por falta de interesse, bem como a manutenção dessa ignorância para o benefício da liberdade das corporações, conforme Brian Holmes (Critical Art Ensemble, 2012).

0 arte-ativismo hacker promove táticas disruptivas no espaço e na temporalidade da matriz performativa cibernética, discutida pelos coletivos CAE e EDT. Corporificações de código interferem nas relações do mundo existente. Nesse sentido, a proposta inicial do CAE (1994) de concentrar a resistência política no ciberespaço se reconfigura e se atualiza para produção posterior do próprio grupo e de outro semelhantes.

Afirma-se assim a aliança entre as corporificações da esfera informacional e os corpos desobedientes das ruas, conforme transparece nos casos mencionados aqui. Conforme o EDT (2010), a fluidez da corporificação permite ao hacktivismo transcender protocolos relacionados ao gênero, raça, sexualidade, religião e outras categorizações corporais. Isso não significa a isenção ou a indiferença ante as malhas respectivas de retenção. Mas viabiliza a reprogramabilidade e a protensão constante e híbrida dos fluxos da performance maquínica disruptiva.

\section{Considerações}

Podemos entender a performance como fluxo retroalimentador da valorização do âmbito processual da poiésis na atividade artística, tecnológica e filosófica. Pois, segundo uma concepção cibernética, a performance se comporta como elemento de entrada e de saída. Porque ela acentua na corporeidade que lhe é peculiar os ritmos do encadeamento 
maquínico que perfaz os diferentes diagramas de potências produtivas e suas incitações de eficiência, efetividade e eficácia.

Não parece casual que isso se coincida e incida sobre o contexto da metamídia informacional. Pois a constituição tecnológica está atrelada e impulsiona adiante a atração pela dinâmica compartilhada por práticas artísticas e teóricas, bem como outras situações operacionais, cognitivas e estéticas de alcance político ou econômico. Em torno desse eixo processual de concorrência da performance das corporações, dos aparelhos tecnológicos e dos agentes culturais, a abordagem artística assume propensão ativista e de transgressão hacker, e vice-versa.

Anonymous, Wikileaks e casos semelhantes estabelecem modos de endereçamento político dos efeitos estéticos. Por outra parte, Critical Art Ensemble, Electronic Disturbance Theater e outras denominações artísticas coletivas e individuais assumem sua implicação com as estruturas de sustentação e recomposição do poder. Os projetos que realizam atravessam o ativismo e a arte, sem estacionar em um polo ou outro. Bits, genes e partículas tornam-se meios e contextos de contestação sóciopoética, bio-poética, físico-poética.

Com essa vinculação ética, a performance maquínica do arte ativismohacker propaga no mundo a reprogramabilidade advinda da abstração (matemática) do próprio mundo. Varia aquilo que performa, a corporificação específica e ajustada a cada circunstância. As respectivas linguagens programáticas em fluxo marcam os -gramas nos suportes materiais e psíquicos de retenção, abrindo malha para a protensão transitiva em ciclos performáticos que se sucedem, em compasso com as batalhas orientadas pelos diagramas de poder.

O arte ativismo-hacker se converte em tendência da performance artística situada na realidade informacional contemporânea. Nessa situação crítica, 
aparentemente, todo resquício, o que resta, é irresistível à recuperação e transformação. Se esse recurso está também na base de estratégias opressivos, pode ser reclamado, reapropriado, em linguagens táticas de dissidência.

Texto e mundo - a reprogramar.

\section{Referências}

BAZZICHELLI, Tatiana. Networked Disruption: Rethinking Oppositions in Art, Hacktivism and Business [catalogue of the exhibition curated by Tatiana Bazzichellij. Ljubljana: Aksioma - Institute for Contemporary Art, 2015. Disponível em: <http://aksioma.org/networked.disruption>. Acesso em: 5 abr. 2016.

BAZZICHELLI, Tatiana. Networked Disruption: Rethinking Oppositions in Art, Hacktivism and the Business of Social Networking. Aarhus: Aarhus University, 2013.

BERNHARD, Hans; LIZVLX; LUDOVICO, Alessandro. UBERMORGEN.COM: Media Hacking Vs. Conceptual Art. Basel: Christoph Merian Verlag, 2009.

COLEMAN, Gabriella. Hacker. In: RYAN, Marie-Laure; EMERSON, Lori; ROBERTSON, Benjamin J. (Org.). The Johns Hopkins Guide to Digital Media. Baltimore: Johns Hopkins University Press, 2014a. p. 245-248.

COLEMAN, Gabriella. Hacker, hoaxer, whistleblower, spy: the many faces of Anonymous. London: Verso, 2014b.

CRITICAL ART ENSEMBLE. Digital Resistance: Explorations in Tactical Media. New York: Autonomedia, 2001.

CRITICAL ART ENSEMBLE. Disturbances. London: Four Corners Books, 2012.

CRITICAL ART ENSEMBLE. The Electronic Disturbance. New York: Autonomedia, 1994.

DELEUZE, Gilles. Espinosa: Filosofia Prática. São Paulo: Escuta, 2002.

DENNING, Dorothy E. Activism, Hacktivism, and Cyberterrorism: The Internet as a Tool for Influencing Foreign Policy. In: ARQUILLA, John; RONFELDT, David (Org.). Networks and Netwars: The Future of Terror, Crime, and Militancy. Santa Monica: RAND, 2001. p. 239-288.

DERRIDA, Jacques (1967). Gramatologia. São Paulo: Perspectiva, 1973.

ELECTRONIC DISTURBANCE THEATER; B.A.N.G LAB. Sistemas_Geo_Poéticos (gps): Fragmentos, Fractales, Formas y Funciones contra la Invisibilidad. ERRATA\#, Bogotá, n. 3, p. 22-39, dez. 2010. Disponível em: <http://issuu.com/revistaerrata/docs/errata_3 cultura_digital_creaci_n>. Acesso em: 5 abr. 2016. 
FLUSSER, Vilém. O Mundo Codificado: por uma Filosofia do Design e da Comunicação. São Paulo: CosacNaify, 2007.

FLUSSER, Vilém (1983). Filosofia da caixa preta: ensaios para uma futura filosofia da fotografia. Rio de Janeiro: Relume Dumará, 2002.

FOUCAULT, Michel (1971). A Ordem do Discurso: Aula Inaugural no Collège de France, Pronunciada em 2 de Dezembro de 1970. São Paulo: Loyola, 1996.

GONÇALVES, Fernando do Nascimento. Art, activisme et le transpolitique: étude sur des utilisations artistiques des technologies de la communication en France et au Brésil. Sociétés, Paris, v. 2, n. 104, p. 115-130, 2009. Disponível em: $<$ http://www.cairn.info/resume.php?ID_ARTICLE=SOC_104_0115>. Acesso em: 5 abr. 2016.

HANSEN, Mark B.N. Bodies in Code: Interfaces with Digital Media. New York: Routledge, 2006.

HOLMES, Brian. Hieroglyphs of the future: art \& politics in a networked era. Paris; Zagreb: Visual Culture NGO What, How and for Whom, 2002.

MANOVICH, Lev. Software Takes Command: Extending the Language of New Media. New York: Bloomsbury, 2013.

MCKENZIE, Jon. Hacktivism and Machinic Performance. Performance Paradigm, Sidney, v. 1, n. March, p. 22-30, 2005. Disponivel em: $<$ http://www.performanceparadigm.net/wpcontent/uploads/2007/06/mckenzie.pdf>. Acesso em: 5 abr. 2016.

MCKENZIE, Jon. Perform or else: from discipline to performance. London: Routledge, 2001.

MESQUITA, André Luiz. Arte-ativismo: Interferência, coletivismo e transversalidade. In: ENCONTRO DE HISTÓRIA DA ARTE 22006 CAMPINAS (Org.). Anais... [S.I.]: Unicamp, 2006. p. 1-10. Disponivel em: $\langle$ http://www.ifch.unicamp.br/pos/hs/anais/2006/posgrad/(5).pdf>. Acesso em: 5 abr. 2016.

MESQUITA, André Luiz. Insurgências poéticas: arte ativista e ação coletiva. São Paulo: Fapesp; Annablume, 2011.

OBRIST, Hans-Ulrich. In Conversation with Julian Assange. Part I. e-flux journal, New York, n. 25, 2011a. Disponível em: <http://www.e-flux.com/journal/inconversation-with-julian-assange-part-i/>. Acesso em: 18 nov. 2014.

OBRIST, Hans-Ulrich. In Conversation with Julian Assange. Part II. e-flux journal, New York, n. 26, 2011b. Disponível em: <http://www.e-flux.com/journal/inconversation-with-julian-assange-part-ii/>. Acesso em: 18 nov. 2014.

RALEY, Rita. Tactical Media. Minneapolis: University of Minnesota Press, 2009.

RAUNIG, Gerald. Art and Revolution: Transversal Activism in the Long Twentieth Century. Cambridge: Semiotext(e), 2007.

RENZI, Alessandra. On the Currency of Somatic Architectures of Exchange: An Interview with New Media Artist Ricardo Dominguez. Scapegoat, Toronto, n. 4 (Currency), p. 321-334, 2013. Disponível em: <http://www.scapegoatjournal.org/>.

ROUSE, Margaret; WIGMORE, Ivy. [Corresponding entries]. Whatis.com. Disponivel em: <http://whatis.techtarget.com/>. Acesso em: 18 nov. 2014. 
SERRACINO-INGLOTT, Philip. Is It OK to Be an Anonymous? Ethics \& Global Politics, Stockholm, v. 6, n. 4, 2013. Disponível em: $<$ http://www.ethicsandglobalpolitics.net/index.php/egp/article/view/22527>.

TRIBE, Mark; JANA, Reena. New Media Art. Los Angeles: Taschen, 2006

Artigo recebido em novembro de 2015. Aprovado em abril de 2016 